\title{
Port Efficiency Assessment for Selecting Transit Port for West African Land Locked Countries
}

*Whajah Samuel Miezah"1, Gifty Whajah²

'School of Economics and Management, Shanghai Maritime University, Shanghai, PR China

${ }^{2}$ Future Academy of Science and Technology, 3768 Hunan Highway, Shanghai, P.R China

Corresponding Author: Whajah Samuel Miezah (summysam94@yahoo.com)

\begin{abstract}
Article Info

Volume 8, Issue 4

Page Number : 568-582

\section{Publication Issue}

July-August-2021

\section{Article History}

Accepted : 07 Aug 2021

Published : 14 Aug 2021

The fundamental purpose of this paper is to assess the efficiency of port in West Africa and selectively select the best transit port for landlocked West African countries and for that matter data envelopment analysis will be used for this research. Seven (7) ports were selected out of twelve (12) using container throughput level for the basis of their selection, whiles DEA model was used for the determination of their relative efficiencies and their over time efficiencies through window analysis. It is noted that. The study noted that based on the operational efficiency of the port of Tema in Ghana, port Lomé and port of Douala, they should serve and standout as the transit port when it comes to West African landlocked countries selecting of transit port. It is recommended that there should be an expansion in infrastructure which is which should be the target so as to improve operational efficiency in West African port. Ports authorities should look more into that because is the beacon of ports efficiency and performance, because infrastructure propels ports mass production once those infrastructures are properly utilized.
\end{abstract}

Keywords : Port, Efficiency, West Africa, transit, landlocked, Countries

\section{INTRODUCTION}

Arrive with no coastline is ordinarily named as landlocked state or nation which is a sovereign state all alone. Landlocked Nations (LLCs) utilizes seaports of beach front nations, generally called Travel Nations (TCs) is a legitimate directly under the Unified Countries Tradition on the Law of the Ocean (UNCLOS) [1]. In this manner seaside states are ordered to open their ports for these LLCs to utilize.
(Burkina Faso, Mali and Niger) don't have entry which makes them landlocked. There are 16 nations that makes up West Africa and of these nations and do thirteen have guide access to the ocean whiles the previously mentioned nations don't have. For customary purposes, the three LLCs have been utilizing neighbouring francophone beach front nations as their travel passages [2]. 
These three LLCs in West Africa are all previous French provinces. Colonization realized the foundation of various dialects, monetary standards and fringes. Subsequently, the French had eleven made themselves of (11) provinces, whiles England and Portugal controlled four and one separately [3]. LLCs are comprised of thirteen different choices for decision of travel halls however that has not been the reason because of assorted qualities of causes including the high cost of developing and keeping up new travel passages and contrasts in dialects and monetary forms, which have acted to ensure the prevalence of these standard or customary passageways" [4].

Additionally, English speaking nations like Ghana and Nigeria have throughout the years been an outsider landlocked hinterland to the extent travel exchange of is concerned. The Financial People group of West African States (ECOWAS) and other provincial cooperatives be that as it may, as time passed by have executed upon with loads of endeavours to improve transport and correspondence systems. The administration of sea supply was made workable for the LLCs as they could widen their wellspring of supply [5]. Aside these reasons, the political unsteadiness in a few sections of the West African sub area has additionally made it deliberately perilous for the LLCs to keep depending entirely on their conventional Francophone travel passageways. Subsequently of this a portion of the LLCs met up to manufacture a ponder national key strategies to utilize other travel passageways as an or more to their customary ones [6]. Accordingly, travel administrators started investigating different halls, particularly Ghana in the late 1980's. As far back as it was set up, the travel movement through Ghana has gone up on great rate.

The fundamental purpose of this paper is to assess the efficiency of port in West Africa and selectively select the best transit port for landlocked West African countries and for that matter data envelopment analysis will be used for this research [7]. Seven (7) ports were selected out of twelve (12) using container throughput level for the basis of their selection, whiles DEA model was used for the determination of their relative efficiencies and their over time efficiencies through window analysis. a single output which is the container throughput and a number of inputs of port production was applied with the use of the DEA model and the results was that, the Port of Tema located in Ghana and the port of Lomé located in Togo together with the port of Douala which is located in Cameroon has proven beyond reasonable doubt to be the most efficient port in West Africa under the period of this study [8]

\section{MATERIALS AND METHODS}

\section{Data Selection}

With various Seven (7) noteworthy ports in West Africa chose from a sum of 12 ports in the area as far as their throughput with ports, with a yearly throughput of more than 120000 TEUs from a populace of 12 West African ports. From an of period 2006-2013 compartment throughput pattern will be considered under this review. It comprehended the vacillation of throughput after some time and to know the attributes of different ports after some time. To better do a decent examination on Port proficiency assessment utilizing DEA will begin with the suitable decision of your sources of info and yield factors? [9] The sources of info factors for this review incorporates, the quantity of billet, the quantity of straddle bearers, the length of the quay in meters, the terminal zone in hectors and the quantity of forklift trucks with holder throughput every year being the yield variable. The journalist of a DMU is equivalent to one port.

The quantity of compartment at a port will decide what number of vessels will call at that port which will thusly to lessen blockage or increment clog, in light of the fact that with number of billet a port ends up noticeably appealing as less vessels hold up at the 
mooring and as the idiom goes vessels profit adrift and acquire a parcels cost at compartment so no shipproprietor will convey his vessel to bring about cost so they will like to call at port of simple access to billet so at to keep the vessel running in business [10]. The quantity of straddle transporters is additionally a critical gear at the port which likewise utilized for stacking and off stacking compartments at the terminal and furthermore stacking them, this decides how quick a holder can be moved from one terminal or stacking region to the next which indicates the chain of empty freight, so a lesser number of straddle bearer will diminish efficiency whiles more straddle transporter will signify accelerate work to make the clients fulfilled and furthermore make the port appealing.

Add up to quay length is one of the essential contributions of measuring port execution. It decides the kind of vessels or size that can call at port at one point in time and furthermore decides the turnaround time of the vessel. The terminal zone decides the quantity of holders that can stack or apportioned at a specific point in time. Last however the slightest is the quantity of fork lift trucks which is dependable gear which helps in the developments of the compartments once they arrive on the quay, to move them to their particular terminal or yards The five chose information sources are key factors for the Appraisals, estimations, and assessing of port execution and its productivity.

\section{Analytical Model}

Data Envelopment Analysis (DEA) is a nonparametric direct programming based method for assessing the relative proficiency of Decision making units (DMUs) which was presented by Charnes, Cooper, and Rhodes [11], there has been a substantial number of research on DEA models that a bunches of specialists have grown, for example, BCC show (Banker,Charnes,\&Cooper,[12],FDH model[13], SBM model[14],EBM display [15], RBM demonstrate [16] and NEBM[17].As showed in [18], Wellsprings of wastefulness and efficiencies, positioning of DMUs, assessment of the adequacy of program or strategies, administrations assessment, making a quantitative reason for reallocating assets, and so on, these can be recognized by the utilization of DEA. DEA has increased significant consideration as administrative instrument for measuring the execution of DMUs and port execution in the course of the most recent decades.

DEA strategies have been utilized as a part of the endeavour to direct the assessment of port productivity in many research papers over the most recent two decades. As per the information examined, the exploration papers can be ordered into two segments, the principal segment speaks to contemplates investigating cross-sectional information, while the second area manages board information. Both areas of papers do an examination of port execution in the European nations, the Asian nations [19], the USA and Australia [20]. Inquire about works have excluded ports in West Africa as a few creators may concur. Examination of holder terminal in seaports has been effectively connected with the DEA technique in the current years.

DEA strategy application was in the investigations of [21] on the port part. Their proposal was that, crosssegment information ought to be utilized as a part of assessing the viability of the different methods for sorting out port administrations their work was confined to the utilization of the standard DEA strategies, for example, the DEA-CCR display despite the fact that they may have presented numerous yields, for example, port throughput and consumer loyalty what's more, their work was constrained to the one timeframe. 20 seaports were analyzed and picked the measure of the work constrain, consistency of offices and yearly speculation per port and payload as information factors and the quantity of compartments, the level of administration, consumer loyalty and the quantity of ship calls as yield variable. DEA window investigation was assessed by [22] to decide the effectiveness of 11 compartment terminals 
in a time of four years. DEA window examination empowers perception of the adjustments in terminal efficiencies after some time. The information utilized was work number, number of cranes, aggregate quay length, size of capacity as data sources and freight throughput as the yield. The particular decision of info and yield factors is imperative when utilizing DEA demonstrate for basic examination of effectiveness of ports. Indistinct factors may prompt deluding decisions about port proficiency [23]. Information and yield factors should reflect compartment port creation however much as could reasonably be expected [24]. The yield information which are typically used to dissect port execution and the premise which port is looked at is compartment throughput. For the most part, holder port depends on the effective utilization of land, work and capital which are the types of gear on the grounds, the info information utilized for this exploration are the quantity of billet, the quantity of yard gantry cranes, the length of the quay (in meters), the terminal region (in hectares), and the quantity of fork lift trucks in the port over the period under review.

DEA worries about evaluating the productivity of an individual firm. This firm is the basic unit of examination that, taking after total, makes up the specimen for investigation and is commonly characterized as the Unit of Evaluation or the Basic leadership Unit (DMU) [25]. In their review, the wording alludes to the authoritative substance in charge of controlling the procedure of generation and for settling on choices at different levels that may impact the profitable procedure and, the level of proficiency related with it. These incorporate every day operational, here and now strategic and long haul vital choices. DEA can be utilized to gauge the adjusted effectiveness of a firm by contrasting it and other institutionalized units that change a similar gathering of quantifiable positive contributions to similar sorts of quantifiable positive yields. Indeed, this consistency of both the sources of info and yields constitutes a major hidden supposition whereupon the veracity of DEA proficiency measures is based. Without such a presumption, the significance of measuring productivity over any arrangement of DMUs could without a doubt be raised doubt about.

The fundamental standard of using DEA is to quantify the proficiency level of firms inside a given example. In connection to evaluating the legitimacy of the consistency, it is essential that the nature of information sources used by the different ports over the example is comparable. The profitability of any substance is basically the outright measure of yields/sources of info and, consequently the efficiency of every terminal is spoken to by the computed proportion of throughput.

In the connection to DEA, the relative efficiencies of all units of investigation measured by contrasting their profitability. The route in which productivity is figured depends on a presumption that creation displays consistent comes back to-scale. At the end of the day, there are no none economies of scale as the level of beneficial yield changes. The DEA show comparing to this suspicion is named the DEA-CCR demonstrate [19]. Aside from the DEA-CCR show, the DEA-BCC demonstrate [26] is the two DEA models that are generally considered and connected. The fundamental distinction between the set two models is that the previous takes into consideration maybe a more sensible suspicion of variable comes back to-scale, rather than the steady comes back toscale expected in the DEA-CCR show. The DEA-BCC model of the generation outskirts that are assessed by applying the individual methods. The fundamental contrast between them lies with the induction of the projection way from each of the information focuses that speak to the wasteful firms on to the creation outskirts. This is critical since it is the proportionate separation that outcomes from the projection way that effects specifically upon the proficiency gauge determined for a particular wasteful information point.

The fundamental data got from the over two DEA models, i.e. the DEA-CCR demonstrate, the DEA- 
BCC model is regardless of whether a firm can enhance its execution with respect to the arrangement of firms to which it is being looked at. A fluctuation set of firms has the probability to give distinctive proficiency comes about because of the conceivable development of the creation outskirts. This model outlines how the relative effectiveness score of DMU is gotten in DEA, as proposed by [27].

$\operatorname{Max} h_{o}(g, h) \frac{\sum_{f=1}^{s} g_{f} y_{k f}}{\sum_{i=1}^{m} h_{i} x_{i k}}$ for all $o=1,2, \ldots, n$

(a) Where:

Subject to

$\frac{\sum_{r=1}^{s} u_{r} y_{f p}}{\sum_{i=1}^{m} v_{i} x_{i p}} \quad p=1,2 \ldots ., n$

$g_{f} \geq 0, f=1,2, \ldots, s$

$h_{i} \geq 0, i=1,2, \ldots, m$

Where:

$h_{\mathrm{o}}$ is the relative efficiency of o-th DMU, $y_{\mathrm{kf}}$ indicates the amount of output $\mathrm{f}$ produced by DMU $\mathrm{p}$, with $x_{i \mathrm{p}}$ representing the amount of input $\mathrm{i}$ used by DMU $\mathrm{p}, \mathrm{n}$ on the other hand stands for the number of DMUs, whiles $\mathrm{m}$ is the number of inputs, $\mathrm{s}$ constitute the number of outputs, where as gf is the weight given to output $f$ with hi being the weight given to input $i$.

The model above is solved $\mathrm{n}$ times to evaluate the relative efficiency of each DMU. Mathematically, the non-negative constraints (c) and (d) are not sufficient for the fractional (b) to have a positive value. Due to that it is assumed that all weights for inputs and outputs assign some non zero value.

Since the efficiency of o-th DMU is maximized by solving the expressions (a), (b), (c) and (d) it is obvious that $h_{\mathrm{o}}$ will take values from 0 to 1 . If the value for $h_{\text {ois }}$ equal to 1 , then the o-th DMU will be efficient relative to other DMUs; if jot so, the value of $h_{\mathrm{o}}$ indicates the inefficiency of o-th DMU. The inefficiency of some DMU can be treated as "less efficient DMU" if the value of $h_{\mathrm{o}}$ is close to 1 .

$\operatorname{Max} h_{o}(g, h)=\sum_{r=1}^{s} g_{r} y_{r}$ for all $o=12, \ldots, n$
Subject to

$\sum_{i=1}^{m} h_{i} x_{i}=1$

$\sum_{f=1}^{s} g_{r} h_{r}-\sum_{i=1}^{m} h_{i} p_{i} \leq 0 p=1,2, \ldots, n$

$g_{r} \geq \gamma, f=1,2, \ldots s$

$h_{i} \geq \gamma, \quad i=1,2, \ldots . m$

$h_{o}$ - Relative efficiency of o-th DMU;

$\mathrm{n}$ - Number of DMUs that should be compared;

$\mathrm{m}$ - Number of input values;

$\mathrm{s}$ - Number of output values;

$g_{f}$ - Weight of the output value f;

$h_{i}$ - weight of the input value $\mathrm{i}$.

If $h_{\mathrm{o}}$ has a value in the objective function which is equal to 1 , then o-th DMU is relatively efficient. Moreover, if it is less than 1, then DMU o is relatively inefficient and the value of ho shows the percentage by which DMU should decrease its inputs. DMU o can be considered fully efficient if only the values of other DMUs do not provide the evidence that any of its inputs or outputs could be improved without impairing any other input or output. Looking at expressions (e), (f), (g), (h) and (i) it is obvious that time as a component is not incorporated.

Another way of using the DEA method in time series mode is the Window Analysis. This mode is described as; A DMU in each period is a different DMU and the data for use in the analysis is panel data. The performance of a DMU is compared with its performance in other periods of time and with other DMUs in the same period of time. For instance, if $n$ DMUs in $\mathrm{Y}$ periods of time are considered, then a total of yxY DMUs need to be assessed simultaneously since DMU in year 1 is treated as a different DMU as compared to the same DMU in year 2. 


\section{RESULTS}

With an aggregate number populace of 12 West African ports 7 noteworthy ports were chosen in view of their yearly throughput of 120,000TEUs. The concentrated of this review depended on the operational effectiveness to drive LLCs settle on the finest choice to the extent port choice is concerned. Its regularly understand that, larger part of ports in West Africa are usually regulated by a concession and are for the most part observed to be both committed billet and terminal and multi-reason compartments. With the end goal of material soundness this review dissected the information in view of these devoted terminals. These compartment terminals are those that frequently participate in the treatment of containerised payload at the ports and are likewise the fundamental terminal for such operations. Ports dissected are introduced in Table 3 beneath

Table 1. Selected ports with their respective container Throughput for (2006-2013)

$$
\text { Container Throughput(TUEs) }
$$

\begin{tabular}{|c|c|c|c|c|c|c|c|c|c|}
\hline PORT & TERMINAL & 2006 & 2007 & 2008 & 2009 & 2010 & 2011 & 2012 & 2013 \\
\hline $\begin{array}{l}\text { PORT OF } \\
\text { TEMA }\end{array}$ & $\begin{array}{l}\text { MPS } \\
\text { TERMINAL }\end{array}$ & 325,408 & 489,147 & 555,009 & 525,694 & 590,147 & 656,899 & 824,238 & 793,312 \\
\hline $\begin{array}{l}\text { PORT OF } \\
\text { ABIDJAN }\end{array}$ & SETV TERMINAL & 407,100 & 431,809 & 552,358 & 610,185 & 561,535 & 546,417 & 633,917 & 745,102 \\
\hline $\begin{array}{l}\text { PORT OF } \\
\text { DAKAR }\end{array}$ & $\begin{array}{l}\text { DPWORLD } \\
\text { TERMINL }\end{array}$ & 275,876 & 414,457 & 347,483 & 331,076 & 349,231 & 369,137 & 383,603 & 428,171 \\
\hline $\begin{array}{l}\text { PORT OF } \\
\text { LOMÉ }\end{array}$ & $\begin{array}{l}\text { BOLLORE } \\
\text { AFRICA } \\
\text { LOGISTICS }\end{array}$ & 215,892 & 227,891 & 296,109 & 354,480 & 339,853 & 352,695 & 288,381 & 346,234 \\
\hline $\begin{array}{l}\text { PORT OF } \\
\text { COTONOU }\end{array}$ & $\begin{array}{l}\text { BOLLORE } \\
\text { AFRICA } \\
\text { LOGISTICS }\end{array}$ & 140,300 & 167,791 & 193,745 & 242,820 & 316,744 & 334,798 & 348,190 & 388,341 \\
\hline $\begin{array}{l}\text { LAGOS } \\
\text { PORT } \\
\text { COMPLEX }\end{array}$ & $\begin{array}{l}\text { APM } \\
\text { TERMINALSAPA } \\
\text { PA }\end{array}$ & 477,600 & 611,100 & 710,800 & 610,500 & $1,128,171$ & $1,413,273$ & $1,623,141$ & $1,010,836$ \\
\hline$\frac{\text { PORT OF }}{\underline{\text { DUOALA }}}$ & $\begin{array}{l}\frac{\text { BOLLORE }}{\text { AFRICA }} \\
\underline{\text { LOGISTICS }}\end{array}$ & $\underline{130,700}$ & $\underline{226,200}$ & $\underline{228,100}$ & $\underline{304,800}$ & $\underline{214,135}$ & $\underline{223,674}$ & $\underline{375,358}$ & $\underline{282,342}$ \\
\hline
\end{tabular}




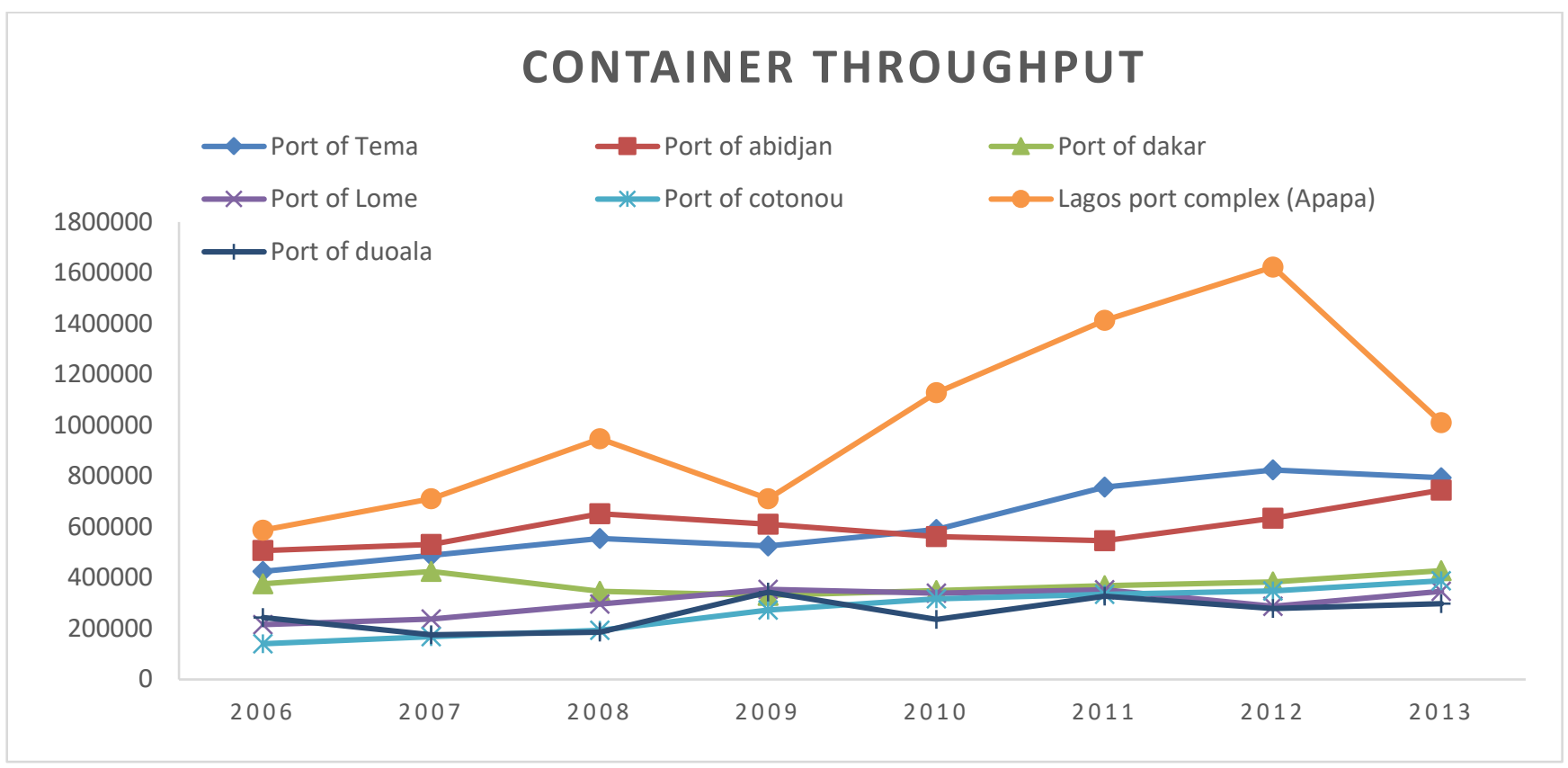

Figure 1. Trend in Container Throughput from (2006-2013)

The above figure speaks to throughputs of 2006-2013 from chose ports. Lagos port complex has the most noteworthy throughput in the above figure yet encounter a few patterns of variety during the time under review. A portion of alternate ports too delineated some type of high points and low points (variety) in some indicate in time just the selectiveness of the port of Cotonou which has an upward pattern up unto 2013. The Choice of port input and output variables are extremely notable, given that an indistinct variable may prompt deceiving supposition about port execution. This variable ought to ponder efficiency however much as could reasonably be expected. The input data and output data specified in the past part can be seen the table 5 underneath. The table likewise demonstrate the framework advancement consistently. It has demonstrated that the greater part of the ports have not really had any significant turnaround or change being developed during the time with the prohibition of port of Tema, Lomé and Douala. The port of Lagos leads as far as infrastructural advancement.

Table 4. Variables for various ports on Input and Output.

\begin{tabular}{|llllllll|}
\hline Ports & Year & $\begin{array}{l}\text { Container } \\
\text { Throughput } \\
\text { (TUE) }\end{array}$ & $\begin{array}{l}\text { Number } \\
\text { of berth }\end{array}$ & $\begin{array}{l}\text { Number } \\
\text { of } \\
\text { Straddle } \\
\text { carrier }\end{array}$ & $\begin{array}{l}\text { Length of } \\
\text { Quay in } \\
\text { meters }\end{array}$ & $\begin{array}{l}\text { Number of } \\
\text { terminals }\end{array}$ & $\begin{array}{l}\text { Number of } \\
\text { fork lift } \\
\text { trucks }\end{array}$ \\
\hline Port Of Tema & 2006 & 425,408 & 14 & 5 & 574 & 10 & 7 \\
\hline 2007 & 489,147 & 14 & 5 & 574 & 10 & 7 \\
\hline 2008 & 555,009 & 14 & 5 & 574 & 10 & 7 \\
\hline 2009 & 525,694 & 14 & 5 & 574 & 10 & 9 \\
\hline
\end{tabular}


Whajah Samuel Miezah et al Int J Sci Res Sci \& Technol. July-August-2021, 8 (4) : 568-582

\begin{tabular}{|c|c|c|c|c|c|c|c|}
\hline & 2011 & 756,899 & 14 & 5 & 574 & 10 & 9 \\
\hline & 2012 & 824,238 & 14 & 13 & 574 & 10 & 9 \\
\hline & 2013 & 793,312 & 14 & 13 & 574 & 10 & 9 \\
\hline \multirow{8}{*}{$\begin{array}{l}\text { Port Of } \\
\text { Abidjan }\end{array}$} & 2006 & 507100 & 10 & 11 & 1000 & 34 & 14 \\
\hline & 2007 & 531,808 & 10 & 11 & 1000 & 34 & 14 \\
\hline & 2008 & 652,357 & 10 & 11 & 1000 & 34 & 14 \\
\hline & 2009 & 610,184 & 10 & 16 & 1000 & 34 & 14 \\
\hline & 2010 & 561,535 & 10 & 16 & 1000 & 34 & 14 \\
\hline & 2011 & 546,416 & 10 & 16 & 1000 & 34 & 14 \\
\hline & 2012 & 633,916 & 10 & 16 & 1000 & 34 & 14 \\
\hline & 2013 & 745,101 & 10 & 16 & 1000 & 34 & 14 \\
\hline \multirow{8}{*}{$\begin{array}{l}\text { Port Of } \\
\text { Dakar }\end{array}$} & 2006 & 375,876 & 9 & 7 & 660 & 35 & 9 \\
\hline & 2007 & 424,457 & 9 & 7 & 660 & 35 & 9 \\
\hline & 2008 & 347,483 & 9 & 8 & 660 & 35 & 9 \\
\hline & 2009 & 331,076 & 9 & 8 & 660 & 35 & 9 \\
\hline & 2010 & 349,231 & 9 & 10 & 660 & 35 & 9 \\
\hline & 2011 & 369,137 & 9 & 10 & 660 & 35 & 9 \\
\hline & 2012 & 383,903 & 9 & 10 & 660 & 35 & 9 \\
\hline & 2013 & 428,171 & 9 & 10 & 660 & 35 & 9 \\
\hline \multirow[t]{8}{*}{ Port of Lomé } & 2006 & 215,892 & 12 & 1 & 430 & 12 & 10 \\
\hline & 2007 & 237,891 & 12 & 1 & 430 & 12 & 10 \\
\hline & 2008 & 296,109 & 12 & 1 & 430 & 12 & 10 \\
\hline & 2009 & 354,480 & 12 & 3 & 430 & 12 & 10 \\
\hline & 2010 & 339,853 & 12 & 3 & 430 & 12 & 10 \\
\hline & 2011 & 352,695 & 12 & 3 & 430 & 12 & 10 \\
\hline & 2012 & 288,481 & 12 & 3 & 430 & 12 & 10 \\
\hline & 2013 & 346,234 & 12 & 3 & 430 & 12 & 10 \\
\hline \multirow{8}{*}{$\begin{array}{l}\text { Port Of } \\
\text { Cotonou }\end{array}$} & 2006 & 140,500 & 11 & 5 & 540 & 20 & 8 \\
\hline & 2007 & 167,791 & 11 & 5 & 540 & 20 & 8 \\
\hline & 2008 & 193,745 & 11 & 5 & 540 & 20 & 8 \\
\hline & 2009 & 272,820 & 11 & 10 & 540 & 20 & 8 \\
\hline & 2010 & 316,744 & 11 & 10 & 540 & 20 & 8 \\
\hline & 2011 & 334,798 & 11 & 10 & 540 & 20 & 8 \\
\hline & 2012 & 348,190 & 11 & 10 & 540 & 20 & 8 \\
\hline & 2013 & 388341 & 11 & 10 & 540 & 20 & 8 \\
\hline
\end{tabular}


Continued

\begin{tabular}{|c|c|c|c|c|c|c|c|}
\hline Port & Year & $\begin{array}{l}\text { Container } \\
\text { throughput } \\
\text { (TUE) }\end{array}$ & $\begin{array}{l}\text { Number } \\
\text { of berth }\end{array}$ & $\begin{array}{l}\text { Number } \\
\text { of } \\
\text { straddle } \\
\text { carriers }\end{array}$ & $\begin{array}{l}\text { Length of } \\
\text { Quay in } \\
\text { meters }\end{array}$ & $\begin{array}{l}\text { Number of } \\
\text { terminals }\end{array}$ & $\begin{array}{l}\text { Number of } \\
\text { fork lift } \\
\text { trucks }\end{array}$ \\
\hline \multirow{8}{*}{$\begin{array}{l}\text { Lagos Port } \\
\text { Complex }\end{array}$} & 2006 & 587,600 & 14 & 11 & 1005 & 55 & 13 \\
\hline & 2007 & 711,100 & 14 & 11 & 1005 & 55 & 13 \\
\hline & 2008 & 947,400 & 14 & 11 & 1005 & 55 & 13 \\
\hline & 2009 & 710,800 & 14 & 12 & 1005 & 55 & 13 \\
\hline & 2010 & $1,128,171$ & 14 & 12 & 1005 & 55 & 13 \\
\hline & 2011 & $1,413,273$ & 14 & 12 & 1005 & 55 & 13 \\
\hline & 2012 & $1,623,141$ & 14 & 12 & 1005 & 55 & 13 \\
\hline & 2013 & $1,010,836$ & 14 & 12 & 1005 & 55 & 13 \\
\hline \multirow{8}{*}{$\begin{array}{l}\text { Ports of } \\
\text { duoala }\end{array}$} & 2006 & 143,665 & 6 & 5 & 433 & 10 & 6 \\
\hline & 2007 & 175,678 & 6 & 5 & 433 & 10 & 6 \\
\hline & 2008 & 185,755 & 6 & 7 & 433 & 10 & 6 \\
\hline & 2009 & 343,554 & 6 & 7 & 433 & 10 & 6 \\
\hline & 2010 & 236,547 & 6 & 7 & 433 & 10 & 6 \\
\hline & 2011 & 327,854 & 6 & 7 & 433 & 10 & 6 \\
\hline & 2012 & 278,344 & 6 & 7 & 433 & 10 & 6 \\
\hline & 2013 & 298,765 & 6 & 7 & 433 & 10 & 6 \\
\hline
\end{tabular}

The above table 4 indicates both input and output data of which data was collected from Port Management Association for West and Central Africa, Trading economic, World Bank and from major terminal operators of the port and port authorities and subjected through a series of producer by the use of DEASOLVER LV (V8) Window length was 5 which can be seen in Table 5 below which takes into account for the different variation in efficiency over a period of time.

Table 5. Window analysis results.

\begin{tabular}{|c|c|c|c|c|c|c|c|c|c|c|}
\hline & 2006 & 2007 & 2008 & 2009 & 2010 & 2011 & 2012 & 2013 & Average & C-Average \\
\hline \multirow[t]{4}{*}{ Port of Tema } & 0.99 & 0.99 & 1 & 0.99 & 1 & & & & 0.99 & \\
\hline & & 0.99 & 1 & 0.99 & 0.99 & 1 & & & 0.99 & \\
\hline & & & 1 & 0.99 & 0.99 & 1 & 1 & & 1 & \\
\hline & & & & 0.99 & 0.99 & 1 & 1 & 0.99 & 0.99 & 0.99 \\
\hline \multirow[t]{4}{*}{$\begin{array}{l}\text { port of } \\
\text { Abidjan }\end{array}$} & 0.76 & 0.79 & 0.91 & 0.87 & 0.82 & & & & 0.83 & \\
\hline & & 0.74 & 0.83 & 0.79 & 0.76 & 0.75 & & & 0.77 & \\
\hline & & & 0.79 & 0.76 & 0.73 & 0.72 & 0.78 & & 0.76 & \\
\hline & & & & 0.76 & 0.73 & 0.73 & 0.78 & 1 & 0.80 & 0.79 \\
\hline
\end{tabular}


Whajah Samuel Miezah et al Int J Sci Res Sci \& Technol. July-August-2021, 8 (4) : 568-582

\begin{tabular}{|c|c|c|c|c|c|c|c|c|c|c|}
\hline $\begin{array}{l}\text { port of } \\
\text { Dakar }\end{array}$ & 0.83 & 0.88 & 0.76 & 0.74 & 0.72 & & & & 0.79 & \\
\hline & & 0.87 & 0.77 & 0.75 & 0.72 & 0.73 & & & 0.77 & \\
\hline & & & 0.77 & 0.76 & 0.72 & 0.73 & 0.74 & & 0.74 & \\
\hline & & & & 0.78 & 0.70 & 0.71 & 0.72 & 0.75 & 0.73 & 0.76 \\
\hline \multirow[t]{4}{*}{ Port of Lome } & 0.99 & 0.99 & 1 & 1 & 0.99 & & & & 0.99 & \\
\hline & & 0.99 & 1 & 0.99 & 0.99 & 0.99 & & & 0.99 & \\
\hline & & & 1 & 0.99 & 0.99 & 0.99 & 0.99 & & 0.99 & \\
\hline & & & & 1 & 0.99 & 0.99 & 0.99 & 0.99 & 0.99 & 0.99 \\
\hline \multirow[t]{4}{*}{$\begin{array}{l}\text { port of } \\
\text { cotonou } \\
\end{array}$} & 0.84 & 0.84 & 0.80 & 0.80 & 0.79 & & & & 0.81 & \\
\hline & & 0.84 & 0.80 & 0.81 & 0.79 & 0.80 & & & 0.80 & \\
\hline & & & 0.80 & 0.80 & 0.79 & 0.80 & 0.80 & & 0.80 & \\
\hline & & & & 0.78 & 0.72 & 0.78 & 0.78 & 0.80 & 0.77 & 0.80 \\
\hline \multirow[t]{4}{*}{$\begin{array}{l}\text { Lagos port } \\
\text { complex } \\
\text { (Apapa) }\end{array}$} & 0.67 & 0.76 & 0.88 & 0.73 & 1 & & & & 0.81 & \\
\hline & & 0.70 & 0.78 & 0.67 & 0.86 & 1 & & & 0.80 & \\
\hline & & & 0.73 & 0.64 & 0.80 & 0.91 & 1 & & 0.82 & \\
\hline & & & & 0.65 & 0.81 & 0.92 & 1 & 0.76 & 0.83 & 0.81 \\
\hline \multirow[t]{4}{*}{$\begin{array}{l}\text { port of } \\
\text { duoala }\end{array}$} & 0.99 & 0.99 & 0.99 & 1 & 0.99 & & & & 0.99 & \\
\hline & & 0.99 & 0.99 & 1 & 0.99 & 0.99 & & & 0.99 & \\
\hline & & & 0.99 & 1 & 0.99 & 0.99 & 0.99 & & 0.99 & \\
\hline & & & & 1 & 0.99 & 0.99 & 0.99 & 0.99 & 0.99 & 0.99 \\
\hline
\end{tabular}

Table 6 selected ports efficiency and rankings.

\begin{tabular}{|lll|}
\hline \multicolumn{1}{|c}{ Port } & Average Scores & Rank \\
\hline Port Of Tema & $99 \%$ & 1 \\
\hline Port Of Lomé & $99 \%$ & 1 \\
\hline Port of Douala & $99 \%$ & 1 \\
\hline Port Of Lagos Complex (Apapa) & $81 \%$ & 4 \\
\hline Port Of Cotonou & $80 \%$ & 5 \\
\hline Port of Abidjan & $79 \%$ & 6 \\
\hline Port of Darka & $76 \%$ & 7 \\
\hline
\end{tabular}




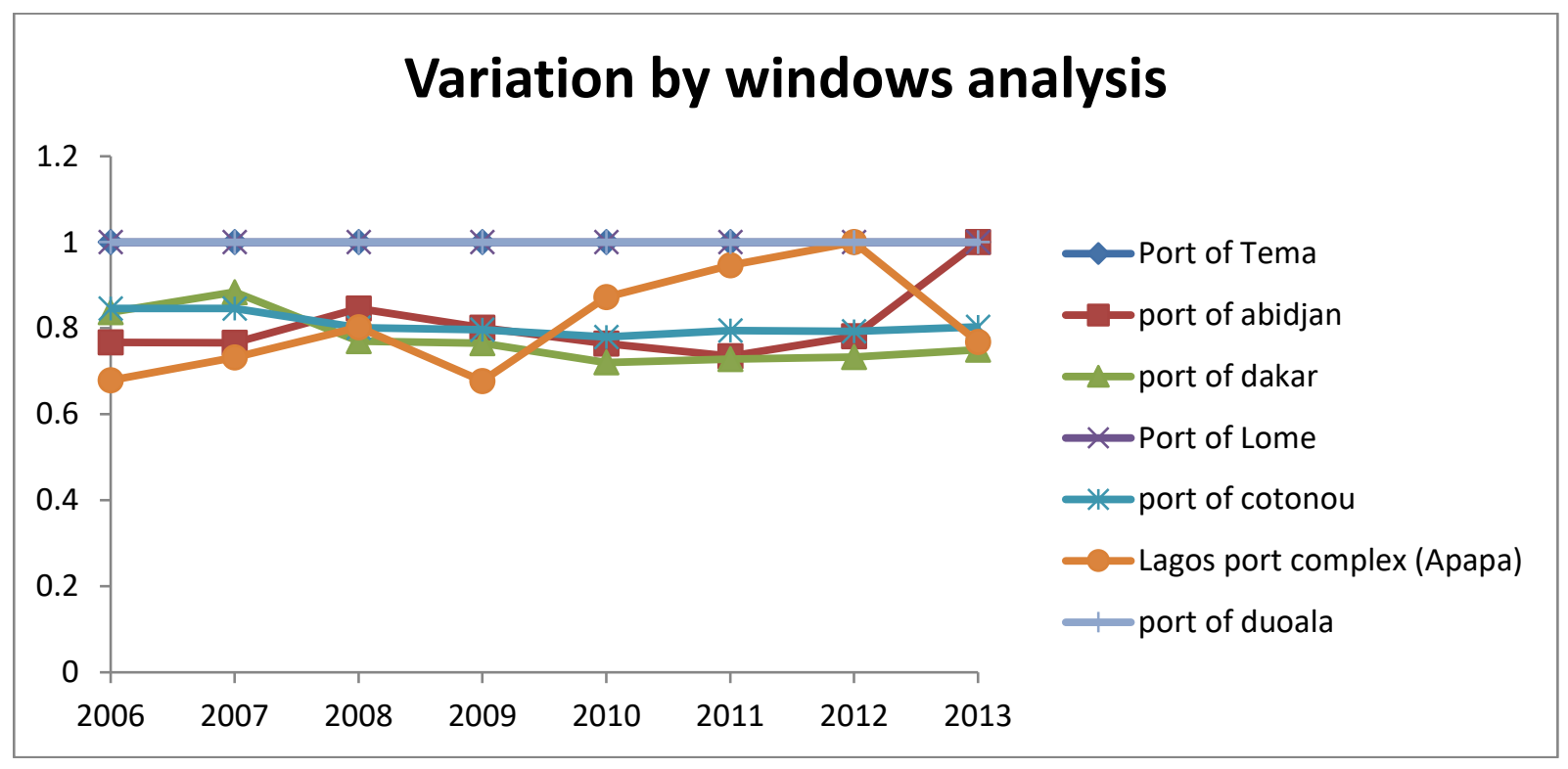

Figure 2 window analysis of Port efficiency variation

Table 7. Port efficiency through window with their averages

\begin{tabular}{|c|c|c|c|c|}
\hline Ports & $\begin{array}{l}2006-2007- \\
2008-2009- \\
2010\end{array}$ & $\begin{array}{l}2007-2008- \\
2009-2010- \\
2011\end{array}$ & $\begin{array}{l}2008-2009- \\
2010-2011- \\
2012\end{array}$ & 2009-2010-2011-2012-2013 \\
\hline Ports of Tema & 0.99 & 0.99 & 1.00 & 0.99 \\
\hline Port of Abidjan & 0.88 & 0.77 & 0.76 & 0.80 \\
\hline Port of Darka & 0.79 & 0.77 & 0.74 & 0.73 \\
\hline Port Of Lomé & 0.99 & 0.99 & 0.99 & 0.99 \\
\hline Port Of Cotonou & 0.81 & 0.80 & 0.80 & 0.77 \\
\hline $\begin{array}{l}\text { Port Of Lagos } \\
\text { Complex (Apapa) }\end{array}$ & 0.81 & 0.80 & 0.82 & 0.83 \\
\hline Port of Douala & 0.99 & 0.99 & 0.99 & 0.99 \\
\hline
\end{tabular}

Table 7 shows the average scores and rank of the ports between $2006-2013$.

Looking at the measure of these three productive

In table 6 we had 5 windows. The length of the window is characterized as five. Four windows are spoken to as four lines for each one port. Each port is spoken to as an alternate DMU at each of the four progressive years. Port of darka experienced low rates in table 6. By this we can substantiate an evidential conclusion that it is the most wasteful one in five windows. Is evidential that it displayed a measure of waste underway as it speak to a normal of $76 \%$ contrasting with the three effective ports score of $99 \%$ utilization of contributions as it never accomplished separately considering the extent of the review. an effectiveness level higher than $82 \%$. 
The port of Tema, Lomé and Douala are the most productive port out of the 7 with a normal score of $99 \%$ which is amazingly remarkable.

This may be to the reason being that they have standard infrastructure. There was an expansion of straddle carrier from 5-13 at Tema port from 2012 to 2013 and also an increment of forklift trucks from 7-9 and these are a noteworthy lift to their infrastructure. Lomé and also Douala additionally had an expansion in their straddle carriers in their year been. In any case, with the eight years under survey, the ports that were most productive were port of Tema, Port of Lomé and the port of Douala in the five windows. In 2006 and 2009 the port of Lagos had a low enrol in its effectiveness however there was an upward ascent between 2010, 2011 and 2012 and still had a drop in 2013 which was because of political distress in the nation. Port of Abidjan additionally encountered a smidgen of high points and low points in the years under review, as it enrolled a low effectiveness in a descending incline from 2008 through to 2011 and quiets down again in 2012 to 2013. The low enrol from 2008 to 2011 was the worldwide monetary emergency on exchange and furthermore a touch of political flimsiness.

Logos port which is known to be Africa's biggest economy and most crowded country was positioned fourth with a normal score of $81 \%$ in this review, having the most noteworthy throughput and an expansive number of contributions among all the 7 ports. The port, notwithstanding, accomplishes a few times of proficiency in the last three windows as it yield expanded fundamentally in that period. This just demonstrates certainty that being huge and expansive does not constituent the better. Furthermore, can be viewed also that its infrastructure was underutilized not making the quite a bit of it. Averagely, all through the period under review, the port of Dakar is said to have enlisted a normal execution. Its least effectiveness occurred in
2009 of $64 \%$ score which happens to be the pattern for the greater part of the port. Be that as it may, it figured out how to make a high effectiveness score with a normal of 81\% in 2007.

\section{CONCLUSION}

The objective of this review is to specifically choose which transit port for landlocked nations in the region to serve West Africa. To locate the most proficient port in West Africa in view of their operations was the set out destinations to achieve this objective. This review exclusively construct it examination with respect to operational efficiency. Data envelopment Analysis was utilized to dissect the Factors of both input and output. General presentation of the dissertation topic can be found in the part one of this review, and furthermore state out the points and goals of the review, giving the method of reasoning of the review and also the extent of the review. Inquire about inquiries were additionally given a similar section.

In the second part which is section two, this review additionally took a gander at the evaluation of port intensity and their compelling elements that impacts the choice of port by shippers and transporters. The review was essentially centred around the operational productivity the review additionally took a gander at different components that have altering variables on port determination, for example, port intensity, shippers on port decision and bearer's port choice as their headings were expressed in the perspective of speculation. Time was additionally taken in this same section to dive into taking a gander at some gear, foundation, offices and a few superstructures, with their conditions as in great state or awful express all in the perspective of moving and improving proficiency in the district.

The approach of this review was introduced in section three where (DEA) Data envelopment Analysis was utilized. DEA is for the most part utilized as a part of port areas about reviews on measuring efficiencies of 
ports and holder terminals. It is a helpful device that can relate multiple inputs and outputs, it additionally requests that information are precise and DMUs are tantamount which on occasion turns into somewhat overwhelming of an errand. From an aggregate of number 12 ports in West Africa, this review did measured the relative proficiency of 7 noteworthy ports in West Africa looking to end up plainly a noteworthy transit port for these land secured nations specified this present review. The information utilized was board information demonstrate from 2006-2013 to demonstrate the relative efficiencies after some time. The applicable information was board information since cross-sectional information may have a miss-bearing and are especially inclined to occasional varieties in productivity which may thus touch base at reaching deluding determinations about the effectiveness of the ports under review. The following inputs variables were chosen for this review which incorporates: number of berth, number of straddle carriers, and length of quay in meters, terminal area and the number of forklift trucks with a solitary output variable, which is container throughput. For as far back as two decades many research ponders have attempted to assess the relative efficiency of benefit in Decision making units (DMUs) utilizing Data Envelopment Units (DEA) which was presented by Charnes, Cooper and Rhodes. This is additionally observed to be a non-parametric straight programming which depends on systems in assessing relative efficiency resources of DMUs. All the primary data for this review was examined and discussed about in chapter four. It is likewise where the dissertation questions were replied in the as relating to the exchange of the essential information gathered, it's additionally where the research question for the review was displayed.

The Port of Tema in Ghana, port of Lomé in Togo and port of Douala in Cameroon in light of the consequences of the model, are the most productive ports with a average score of $99 \%$ with the port of
Lagos taking after with a normal score of $81 \%$ nearly took after by port of

Cotonou and the port of Abidjan with the average score of $80 \%$ and $79 \%$ separately. The review finds that the Port of Darka is slightest effective with an average score of $76 \%$ for each the rankings and indicated impressive waste underway all through the period. Contrasting, Port of Tema, Port of Lomé and the port of Douala ought to be the best decision for landlocked nations to use as a transit port regarding operational efficiency [28]. Essential objective for port authorities is the recommendation for enhancing effectiveness of ports in West Africa which ought to be fundamentally taken a gander at. Looking at the quantity and area size, Lagos port complex Apapa is leading in terms all the input variable mentioned in the study, such as the number of berth, the number of straddle carriers, the length of quay in meters, terminal area and the number of forklift trucks. It is quite fascinating that their efficiency ranks of port were found to be on the $4^{\text {th }}$ place. It clears the doubt that been big is not always the care of being better. It is also of the assumption that, there are too many inputs for a certain level of output or infrastructure may not be at the right area or place or on the other hand facilities were underutilized. My very assurance is that in the future efficiency rank of the port will swing to a better position as long as proper managements are done on the available resources.

There has not been any major infrastructure development between 2006 and 2013 for the Ports of Darka, Abidjan and Lagos port complex this reflected in their efficiency performance throughout the years under study. All the Ports that had major improvement in infrastructure had a good efficiency performance throughout the years under study.

The port of Tema increased its number of straddle carriers from 5 to 13 and their forklift trucks from 7 to 9 which had a significant impact in their rankings as well as port Lomé and port of Douala all had improvement in their infrastructure and as much 
reflected in their rankings as well putting them at par with the port Tema on $1^{\text {st }}$ place.

This becomes very imperative that and improvement in a ports infrastructure will results in a positive outcome in its efficiency rankings amongst the West African ports. A typical example in this study is the Lagos port who might be ranked $1^{\text {st }}$ once its infrastructure is improved. To achieve such improvement will also depend on the recent port privatizations which occurred in the region. Also most West African port experience limitations in term of draft so as to accommodate larger vessels, which would enable the benefit of economies of scale for both shipping lines and shippers. This stands to be stumbling block for these ports. In five to ten years container vessels requiring up to $14 \mathrm{~m}$ draught will be calling at West African ports. This was the forecast of Palsson and his co-creator. The West Africa has numerous ports along its drift and by driving and improving port access for transportation lines, should be possible by the concurring on one port as a transhipment port in the district.

\section{REFERENCES}

[1]. Samuel Pyeatt Menefee " "The Oar of Odysseus": Landlocked and "Geographically Disadvantaged" States in Historical Perspective" 10

[2]. Upretty, The Transit Regime for Landlocked States. 5

[3]. The Convention and Statute on freedom of Transit (adopted 20th April 1921, entered into force 31 October 1922) 171 LNTS Vol 7, p11.

[4]. Evlo, K. (1994). Transit transport systems in West and Central Africa: Issues, actions and constraints. Geneva: UNCTAD

[5]. Arvis, J-.F., Gael, R. and Jean-Francois, M. (2010) The Cost of Being Landlocked: Logistics Costs and Supply Chain Reliability. World Bank, Washington DC. https://doi.org/10.1596/978-0-8213-8408-4
[6]. Andrius, J. and Aidas, V.V. (2007) Research on Dry Port Concept as Intermodal Node. Transport, 22, 207-213.

[7]. Limao, N. and Venables, A.J. (2001) Infrastructure, Geographical Disadvantage, Transport Costs and Trade. The World Bank Economic Review, 15, 451-479. https://doi.org/10.1093/wber/15.3.451

[8]. Tom, V. and Cathy, M. (2016) Intermodal Land Transportation Systems and Port Choice, an Analysis of Stated Choices among Shippers in the Rhine-Scheldt Delta. Maritime Policy \& Management, $\quad 43, \quad 992-1004$. https://doi.org/10.1080/03088839.2016.1172277

[9]. Malchow, M. and Kanafani, A. (2001) A Disaggregate Analysis of Factors Influencing Port Selection. Maritime Policy and Management, 28, 265-277. https://doi.org/10.1080/03088830110060840

[10]. McGinnis, M.A. (1979) Shipper Attitudes toward Freight Transportation Choice: A Factor Analytic Study. International Journal of Physical Distribution and Materials Management, $\quad 10, \quad 25-34$. https://doi.org/10.1108/eb014464

[11]. Charnes, A., Cooper, W.W. and Rhodes, E. (1978) Measuring the Efficiency of Decision Making Units. European Journal of Operational Research, 2 , 429-444. http://dx.doi.org/10.1016/0377-2217(78)90138-8

[12]. Banker, R., Charnes, A. and Cooper, W. (1984) Some Models for Estimating Technical and Scale Inefficiencies in Data Envelopment Analysis. Management Science,30,1078-1092. http://dx.doi.org/10.1287/mnsc.30.9.1078

[13]. Roll, Y. and Hayuth, Y.: Port performance comparison applying data envelopment analysis, Maritime Policy and Management, Vol.20,No.2,1993, pp.153-161

[14]. Min, H., Park, B.I.: Evaluating the intertemporal efficiency trends of international container terminals using data envelopment 
analysis, Int. J. Integrated Supply Management, Vol. 1, No. 3, 2005, pp 258-277

[15]. Stopford, M. (1997). Maritime Economics. Abingdon, Oxon: Routledge Tiwari, P., Itoh, H., \&Doi, M. (2003). -Shippers Port and carrier selection 'behaviour in China:' A discrete choice Analysis. Maritime Economics\&Logistics, 5,2339

[16]. Ma, S. (2007). Maritime Economics: Malmo, World Maritime University. (Unpublished).

[17]. Winkelmans, W. (2003). Port competitiveness and Port competition: two of a kind? Paper presented at the IAPH congress, Durban

[18]. Ugboma, C., Ugboma, \&Ogwude, C. I. (2006). An Analytic Hierarchy Process (AHP) Approach to Port Selection Decisions-Empirical Evidence from Nigerian Ports. Maritime Economics \& Logistics, 8,251-266

[19]. Tongzon, J.: Efficiency measurement of selected Australian and other international ports using data envelopment analysis, Transportation Research Part A, Vol. 35, No. 2, 2001, pp 107122

[20]. Cullinane, K.P.B. and Wang, T.F. (2006) The Efficiency of European Container Ports: A Cross-Sectional Data Envelopment Analysis. International Journal of Logistics Research and Applications, $\quad$ 9, 19-31. http://dx.doi.org/10.1080/13675560500322417

[21]. Roll, Y. and Hayuth, Y.: Port performance comparison applying data envelopment analysis, Maritime Policy and Management, Vol.20,No.2,1993, pp.153-161

[22]. Charnes, A., Cooper, W.W. and Rhodes, E. (1978) Measuring the Efficiency of Decision Making Units. European Journal of Operational Research, 2 , 429-444. http://dx.doi.org/10.1016/0377-2217(78)90138-8

[23]. Cullinane, K.P.B. and Wang, T.F. (2006) The Efficiency of European Container Ports: A Cross-Sectional Data Envelopment Analysis. International Journal of Logistics Research and
Applications,

9 ,

19-31. http://dx.doi.org/10.1080/13675560500322417

[24]. Cullinane, K.P.B., Wang, T.F. and Cullinane, S.L. (2004) Container Terminal Development in Mainland China and Its Impact on the Competitiveness of the Port of Hong

Kong.Transport Reviews, 24, 33-56. http://dx.doi.org/10.1080/0144164032000122334

[25]. Charnes, A., Cooper, W.W. and Rhodes, E. (1978) Measuring the Efficiency of Decision Making Units. European Journal of Operational Research, 2 , 429-444. http://dx.doi.org/10.1016/0377-2217(78)90138-8

[26]. Banker, R., Charnes, A. and Cooper, W. (1984) Some Models for Estimating Technical and Scale Inefficiencies in Data Envelopment Analysis. Management Science,30,1078-1092.

[27]. Charnes, A., Cooper, W.W. and Rhodes, E. (1978) Measuring the Efficiency of Decision Making Units. European Journal of Operational Research, 2, 429-444. http://dx.doi.org/10.1016/0377-2217(78)90138-8

[28]. ITN Source (2014) TOGO: Togo Launches 640 Million US Dollar Berth Expansion at Lomé Port. http://www. itnsource.com/en/shotlist/RTV/2014/10/15/RTV 151014011

\section{Cite this article as :}

Whajah Samuel Miezah, Gifty Whajah, "Port Efficiency Assessment for Selecting Transit Port for West African Land Locked Countries", International Journal of Scientific Research in Science and Technology (IJSRST), Online ISSN : 2395-602X, Print ISSN : 2395-6011, Volume 8 Issue 4, pp. 568-582, July-August 2021. Available at doi : https://doi.org/10.32628/IJSRST218485 Journal URL : https://ijsrst.com/IJSRST218485 